This is an Accepted Manuscript of an article published by Taylor \& Francis in Australasian Journal of Water Resources on 2 Nov 2017, available online: http://www.tandfonline.com/10.1080/13241583.2017.1398365 


\title{
PARAMETER ESTIMATION FOR A LARGE CATCHMENT
}

\author{
PHUONG CU ${ }^{(1)}$, JAMES E BALL $^{(2)}$ \\ (1) School of Civil and Environmental Engineering, University of Technology Sydney, \\ Broadway, NSW, 2007,AUSTRALIA.E-mail:Phuong.Cu@uts.edu.au \\ ${ }^{(2)}$ School of Civil and Environmental Engineering, University of Technology Sydney, \\ Broadway, NSW, 2007, AUSTRALIA.E-mail: james.ball@uts.edu.au
}

\begin{abstract}
Estimation of parameter values is an essential step in the application of catchment modelling systems. This step is time-consuming and requires considerable effort. While a variety of approaches have been developed to accelerate the process, the selection of an approach depends on the problem requiring catchment modelling, the dominant processes influencing the catchment response to storm events and, moreover, the number of parameters that need consideration. This paper will propose a method to reduce significantly the number of parameters for a large catchment when a semi-distributed catchment modelling system is applied. Past studies have reported on the use of a scaling parameter to adjust parameter values from their initial values, introduced herein is the use of a scaling parameter together with a variation coefficient. This enables the spatial variation of changes in parameter values across the catchment to be considered. A case study was conducted for a $14,000 \mathrm{~km}^{2}$ catchment to assess the validity of this approach where the focus of the catchment modelling was the prediction of a design flood statistic. This catchment was divided into 155 subcatchments with 5 sensitive parameters per subcatchment. Hence, a total of 775 parameters needed to be considered. Using the proposed approach, the number of parameters considered during the calibration was reduced to 8 coefficients which was reasonable for a calibration and validation process that also enabled an estimate of the parameter variability.
\end{abstract}

Keywords: catchment modelling system, flood estimation, parameter estimation,

\section{INTRODUCTION}

Model parameters and their values are an essential component for the operation of a catchment modelling system; a catchment modelling system is a system of hydrologic and hydraulic models representing the important catchment processes. These parameters may have a physical significance, or 
they may be empirical. Nonetheless, the estimation of parameter values is a key prerequisite for operation of the catchment modelling system. Estimation of the parameter values can be conducted by direct physical interpretation, measurements at an appropriate scale or fitted during the calibration and validation process.

There have been many studies that have investigated the calibration and validation process in flood estimation (Ballesteros et al., 2011, Kundu et al., 2016, Monnier et al., 2016, Rashid et al., 2016, Viviroli et al., 2009, Yucel et al., 2015, Zhang et al., 2016) and the importance of the calibration metric on the resultant values (Amir et al., 2013, Cameron et al., 1999, Cheng et al., 2014, Cu and Ball, 2016, Liu and Sun, 2010). Also estimation of parameter value uncertainty has been conducted as part of the estimation of prediction uncertainty (Beven and Freer, 2001, Blasone et al., 2008, Del Giudice et al., 2013, Dung et al., 2015, Fan et al., 2016, Franz and Hogue, 2011, Halbert et al., 2016, Jin et al., 2010). In general, the number of parameters requiring evaluation has provided a constraint on many practical applications of the techniques developed in these studies. As outlined later, this study aims to mitigate this limitation.

In the calibration process, the number of parameters that need to be calibrated depends on the model. The more complex the catchment modelling system, the more parameters that need consideration as reported in, for example, MIKE by DHI (2011), Podger (2004), and US Army Corps of Engineers (2010). The number of parameters to be calibrated has posed a problem for large catchments where the parameter values may vary significantly across the catchment and where the adoption of a single value based on a catchment average value may be not appropriate. An approach that allows variation of parameter values across a large catchment is the division of the catchment into a number of elements/grid squares or subcatchments (distributed/semi-distributed system). The resultant catchment modeling system enables detailed modelling of catchment storage at local level and improves the runoff routing process (Singh \& Frevert 2006). However, the number of parameters that need consideration in these distributed/semi-distributed systems increases dramatically and poses a problem in estimation of acceptable model parameter values.

The choice of optimisation and sampling algorithms has a role in estimation of parameter values. Several optimisation and sampling algorithms have been developed, for example: the Shuffled Complex Evolution algorithm (Thyer et al. 1999; Vrugt et al. 2003), the three-phase simulated annealing algorithm SA-SX (Thyer et al. 1999), a genetic algorithm (Ebrahim et al. 2016; Fang \& Ball 2007), Monte Carlo (Martin \& Ayesa 2010), Markov Chain Monte Carlo (Blasone et al. 2008; Cheng et al. 2014; McMillan \& Clark 2009; Vrugt et al. 2013), Bayesian technique (Hutton et al. 2014; Muleta et al. 2013; Smith et al. 2015). These search algorithms, in general, require the generation of a large number of parameter sets from the feasible parameter space to perform the search for parameter values that result in the best simulation of the catchment response. The number of parameters to be evaluated 
influences the number of parameter sets needed to assess simulation of catchment response. As many modelling systems require individual parameter values for each subcatchment (or grid element) the result is a huge number of parameter sets and an unacceptable computational burden.

As initial parameter values can be estimated based on available catchment information, the introduction of multiple coefficients (one coefficient per parameter category) for adjustment of parameter values from their initial values has been reported in several studies. For example, a multiple coefficient (mean coefficient) has been applied to shift parameter values across the catchment by Jin et al. (2010), Houska et al. (2014), and US Army Corps of Engineers (2010). A limitation of these studies was the assumption that parameter values across the catchment uniformly decreased/increased as the coefficient value changed. Hence, the relationship between parameter values at individual points remained constant.

Another optimization approach for parameter estimation is a singular value decomposition approach (SVD) which allows estimation of combinations of correlated parameters rather than the individual parameters based on the initial estimated parameter values. This approach has been reported in a number of groundwater simulation studies (see, for example, McCloskey et al., 2011; Tonkin and Doherty, 2009, Schilling et al., 2014). However, a limitation of the SVD approach is that it deals with linear systems. Hence, while the SVD approach has achieved merits in simulating groundwater systems, it has not been applied for flood estimation where the system response tends to be non-linear.

The focal point of this paper is the presentation of an approach aimed at generating parameter values for calibration of a semi-distributed non-linear flood model of a catchment. The basis of the approach is the use of mean and variation coefficients. The purpose of the mean coefficient is to produce a consistent shift in parameter values across the catchment (see Jin et. al., 2010). On the other hand, the purpose of the variation coefficient is to introduce a random variation into the parameter values after application of the mean shift. The inclusion of the variation coefficient enables parameter values upstream and downstream of gauging stations to vary.

Application of this approach significantly reduces the number of parameters that need consideration in a semi-distributed system. In addition, the sensitivity of parameter category is assessed as the variation coefficient changes the ranges of parameter values across the catchment during the calibration process. A case study for a catchment in Vietnam is presented where a semi-distributed catchment model was applied. The objectives of the catchment modeling in this study were the estimation of design flood statistics. Hence, as discussed by $\mathrm{Cu}$ and Ball (2016), the focus of the study is the replication of flood statistics rather than the replication of individual flow hydrographs. 


\section{METHODOLOGY}

The catchment modelling system used in this study was the semi-distributed model HEC-HMS. US Army Corps of Engineers (2010) describe this model as a numerically based model with semidistributed parameters. The software consists of several options for selection of a loss model, a rainfall model and for runoff generation and channel routing. Presented in this paper will be an example of the application of the SCS curve number as the loss model, a kinematic wave approach for runoff generation and the Muskingum-Cunge technique as a routing model to translate flood waves along channel reach elements. US Army Corps of Engineers (2000) report details of the model physics, structure and parameterisation. Using these process models, the catchment modelling system requires values for 10 parameters for each subcatchment. These parameters are shown in Table 1.

Table 1: Model parameters and potential ranges

Source: (US Army Corps of Engineers 2000)

\begin{tabular}{|c|c|c|c|}
\hline & Models & Parameters & Range \\
\hline 1 & Loss models & Curve number & $20-90$ \\
\hline 2 & \multirow{4}{*}{$\begin{array}{l}\text { Kinematic wave (Overland flow } \\
\text { planes) }\end{array}$} & Typical length & \\
\hline 3 & & Representative slope & $0.0001-1$ \\
\hline 4 & & Overland-flow roughness coefficient & $0.35-0.8$ \\
\hline 5 & & Area represented by plane & \\
\hline 6 & \multirow{5}{*}{$\begin{array}{l}\text { Musking-Cunge routing } \\
\text { (The main channel) }\end{array}$} & Main channel length & \\
\hline 7 & & Description of main channel shape & Rectangular \\
\hline 8 & & Channel slope & $0.0001-1$ \\
\hline 9 & & Channel width & \\
\hline 10 & & $\begin{array}{l}\text { Representative Manning's roughness } \\
\text { coefficient }\end{array}$ & $0.035-0.08$ \\
\hline
\end{tabular}

The spatial discretisation of HEC-HMS relies on the disaggregation of the catchment into subcatchments; each subcatchment will have 10 parameters. As the number of subcatchments increases, the number of parameters increases in direct proportion; $\mathrm{X}$ subcatchments will produce $10 * \mathrm{X}$ parameters. This large number of parameters can cause problems during the calibration process. Reductions in the number of parameters can be achieved by sensitivity analyses reported by Al-Hamdan (2009); Eslamian (2014); Kousari et al. (2010); US Army Corps of Engineers (2000). While this results in a more feasible calibration process for catchments with low numbers of subcatchments, the calibration process remains complicated with dimensionality remaining a problem when the number of subcatchments is large.

This paper proposes a method to reduce the number of parameters requiring calibration when the number of subcatchments is large. Two coefficients namely a mean coefficient $\left(\mathrm{K}_{1}\right)$ and a variation coefficient $\left(\mathrm{K}_{2}\right)$ will be used to change values of parameters in each parameter category across the catchment during the calibration process. The purpose of the mean coefficient is linear shifting of 
parameter values across the catchment, while the variation coefficient aims to change the variation of these parameter values between subcatchments; the capacity to vary the relationship of parameter values between subcatchments is particularly useful when there is more than a single gauging station in the catchment. Hence, adjustment of parameter values during the calibration process is achieved via amendment of these two coefficient values.

For example, if the catchment was divided into $\mathrm{X}$ subcatchments, there will be $\mathrm{X}$ curve numbers $(\mathrm{CN})$ values across the catchment. Noting that the initial value of the $\mathrm{CN}$ for subcatchment $\mathrm{i}$ is $\mathrm{CN}_{\mathrm{i}, 0}$ and the mean values of the initial $\mathrm{CN}$ values for all $\mathrm{N}$ subcatchments is $\overline{C N_{0}}$, a new $\mathrm{CN}$ value at subcatchment $\mathrm{i}$ for step $\mathrm{j}\left(\mathrm{CN}_{\mathrm{i}, \mathrm{j}}\right)$ is calculated by the following equation:

$$
C N_{i, j}=K_{1}\left[\overline{C N_{0}}+\left(C N_{i, 0}-\overline{C N_{0}}\right) K_{2}\right]
$$

Using this approach, the change in $\mathrm{CN}$ values at each new generation parameter set for all subcatchments is obtained by adjustment of $\mathrm{K}_{1}$ and $\mathrm{K}_{2}$. Therefore, instead of a need to amend $\mathrm{X}$ values of $\mathrm{CN}$ to generate a new parameter set, there is a need for adjustment of only 2 coefficients, namely $\mathrm{K}_{1}$ and $\mathrm{K}_{2}$.

The study system consists of $\left(\mathrm{X}^{*} 10\right)$ parameters classified into 10 categories. Through application of this approach, only20 coefficients ( 2 coefficients for 10 categories of parameter) needed to be considered in the calibration and validation process and this number was reduced further to 8 coefficients. This is discussed in the next sections.

\section{TEST CATCHMENT}

The Ba river, Vietnam was chosen as a test catchment for the study being presented herein. This river is located in South Central Vietnam. The catchment area is $13,900 \mathrm{~km}^{2}$ and the total length of the river is $347 \mathrm{~km}$ with its headwaters in Kon Tum province and ultimately flowing into the South Sea at Tuy Hoa in Phu Yen Province (VKH KTTV\&MT 2010).

The catchment is located in a tropical monsoonal climatic regime. The main features of this climate regime are extraordinarily rainy wet seasons and pronounced dry seasons. Foehn wind and tropical cyclones strongly affect the area during the wet season. A distinct cyclone season occurs later in the summer period from September to December, sharply peaking in October (VKH KTTV\&MT 2010). During a thunderstorm, the maximum 24-hour rainfall can be as much as 228mm (19/11/1987) at Pleiku station, 628.9mm (03/10/1993) at Tuy Hoa station and 579mm (04/10/1993) at Son Hoa station (HMDC 2012). Flooding is a common phenomenon in the Ba River catchment. The largest recorded flood peak 
at the Cung Son gauging station is $20,700 \mathrm{~m}^{3} / \mathrm{s}$. Shown in Table 2 are some recorded peak flood flows at different locations across the basin.

Table 2: Flood flow observation period of Ba River

Source (HMDC 2012)

\begin{tabular}{|l|l|l|l|c|c|}
\hline$T T$ & Gauge & River & $F l v\left(\mathrm{~km}^{2}\right)$ & Observation years & Observation period \\
\hline 1 & An Khe & $\mathrm{Ba}$ & 1350 & 35 & $1977-2011$ \\
\hline 2 & Cung Son & $\mathrm{Ba}$ & 12410 & 35 & $1977-2011$ \\
\hline 3 & Song Hinh & $\mathrm{Hinh}$ & 747 & 13 & $1980-1992$ \\
\hline
\end{tabular}

\section{Input data}

\section{Rainfall Model and Method of Fragments for Rainfall Disaggregation}

Rainfall data: Daily rainfall data are available at 26 stations across the catchment (see Figure 1 for locations of gauges). The daily rainfall records at almost all of these stations are available for more than 30 years covering the period $1980-2011$. However, there are only 12 stations recording hourly rainfall with periods of record ranging from 14 to 33 years. Only 4 gauges have hourly rainfall records more than 30 years from 1976 to 2011.

The limitation of temporal rainfall was improved by using the Method of Fragments to generate hourly rainfall from daily rainfall data. Details of this are presented by Ball \& $\mathrm{Cu}$ (2014). As a result, consistent rainfall at hourly time steps at 26 stations has been generated for the period from 1980 to 2011 . Gridded rainfall was used in the model; this gridded was generated by implementation of an Inverse Distance Weight method.

\section{Flood flow data}

Flow data are observed at 3 stations within the catchment, namely Cung Son, An Khe and Song Hinh. Two gauges, Cung Son and An Khe have discharge data in hourly and 6-hourly intervals for more than 30 years. This 30-year period is from 1980 to 2011. At the Song Hinh gauge, flood flows were available only for 13 years from the period from 1980 to 1992 with discontinuous measurement (HMDC 2012). 


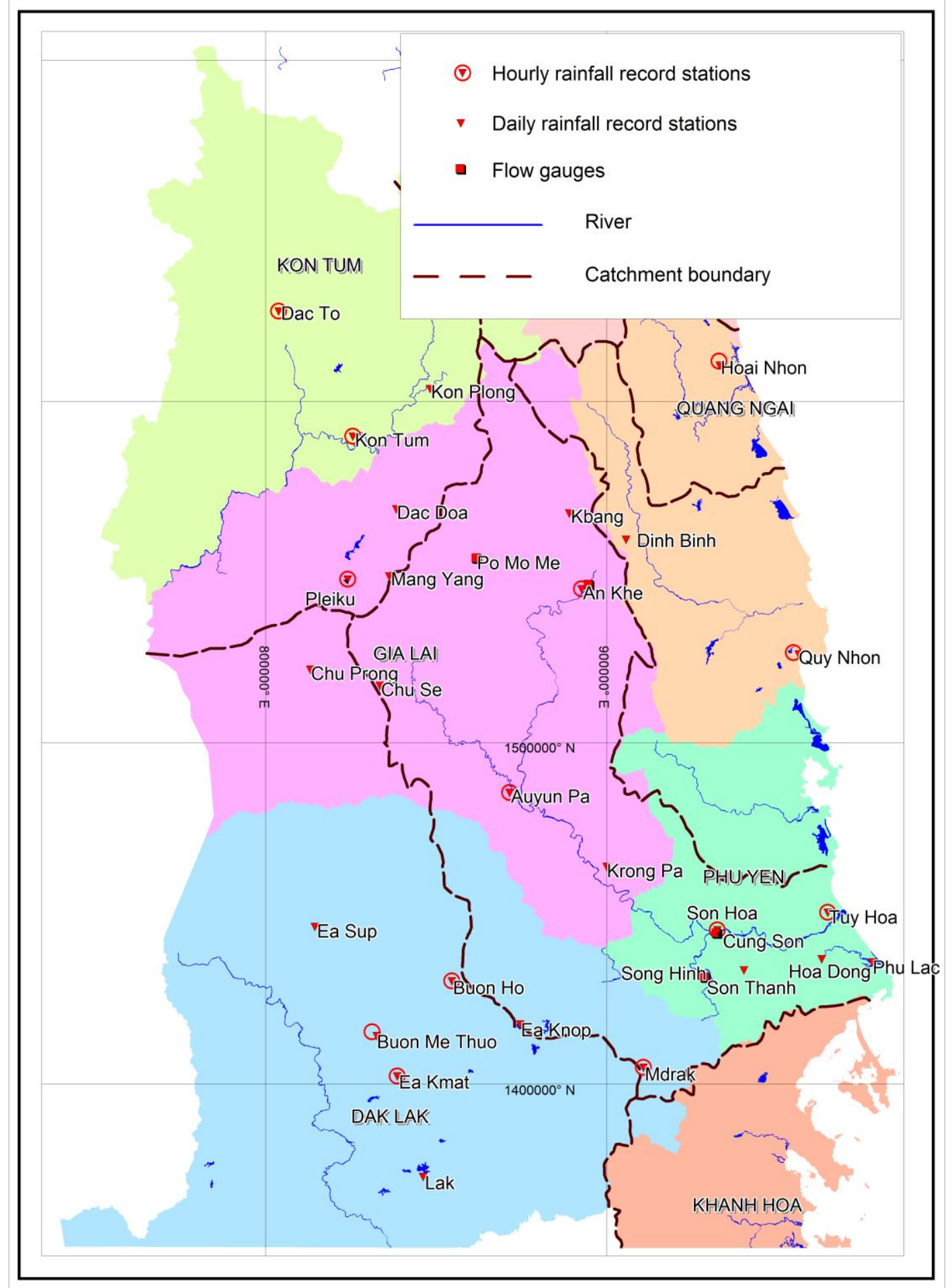

Figure 1: Distribution of meteorological stations across Ba basin

(After KTTV\&MT, 2010) 
Flood flow statistics at two gauges, namely An Khe and Cung Son, were used to calibrate the model. These flood flow statistics were estimated using the FLIKE software (Kuczera 2016). The observed annual maximum series (AMS) was extracted and fitted with a Log-Pearson III (LP-III) distribution using FLIKE. Figure 2 and Figure 3 illustrate the flood frequency curve and the associated confidence limits at two gauges Cung Son and An Khe respectively. Most probable values $(\alpha)$ and standard deviation $(\sigma)$ for each of the LP-III parameters for the An Khe and Cung Son gauges are shown in Table 3 and Table 4.

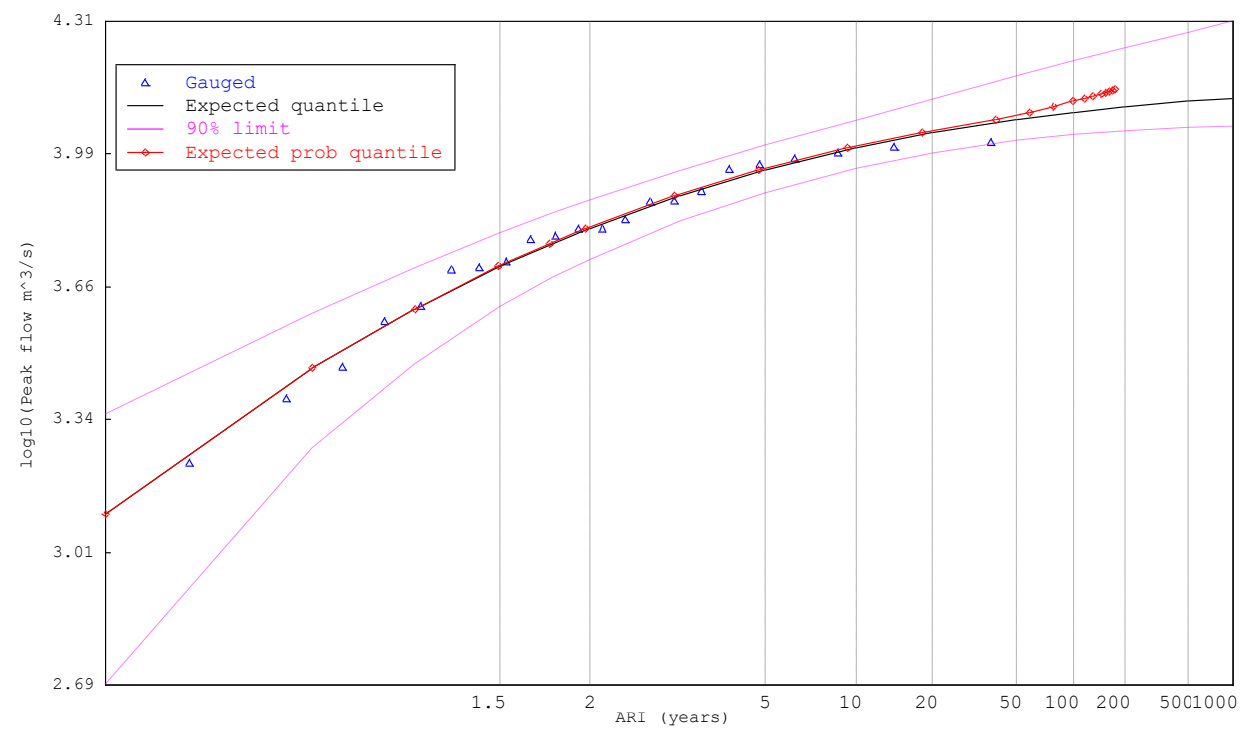

Figure 2: Flood frequency curve at Cung Son gauge

(After Cu \& Ball,2016)

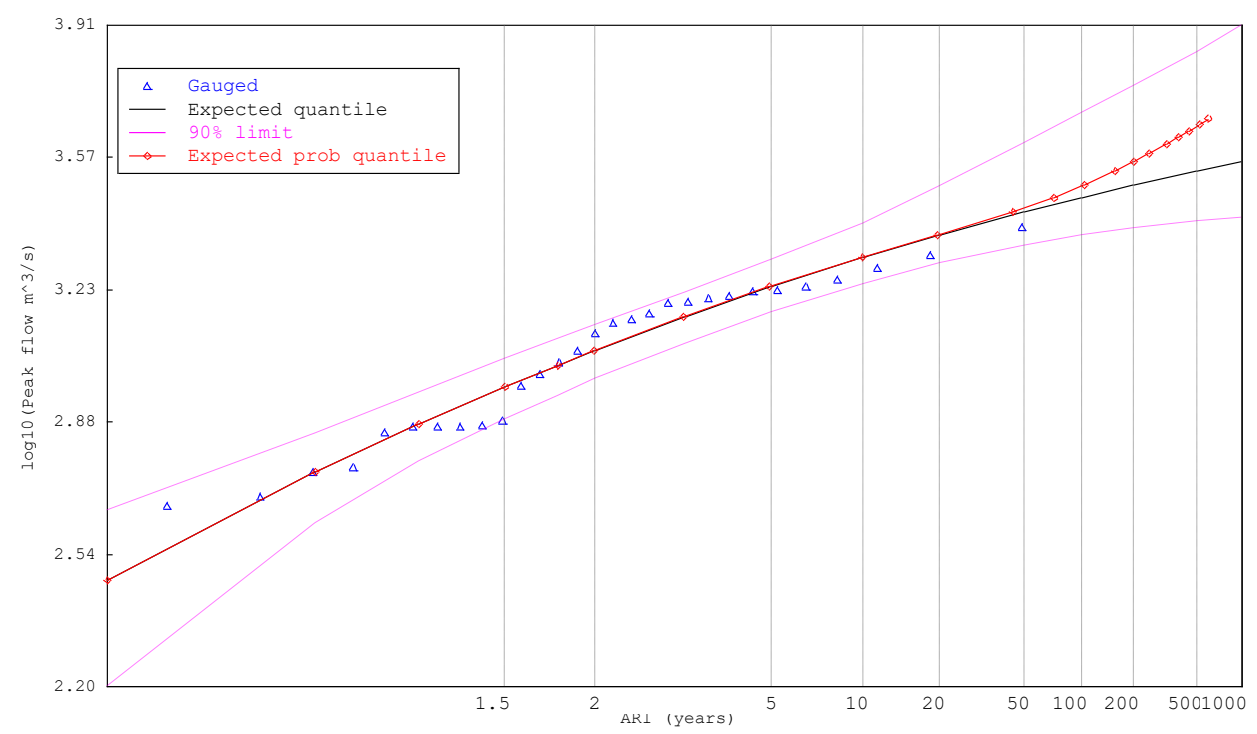

Figure 3: Flood frequency curve at An Khe gauge

(After Cu \& Ball, 2016) 
Table 3: Parameters $(\alpha, \sigma)$ at An Khe gauge

\begin{tabular}{|c|l|c|c|}
\hline $\mathrm{N}$ & \multicolumn{1}{|c|}{ Parameters } & $\begin{array}{c}\text { Most Probable } \\
\text { value }(\alpha)\end{array}$ & $\begin{array}{c}\text { Standard } \\
\text { deviation }(\sigma)\end{array}$ \\
\hline 1 & Mean (loge flow) & 7.0422 & 0.09018 \\
\hline 2 & Loge [Std dev (loge flow)] & -0.74320 & 0.15064 \\
\hline 3 & Skew (loge flow) & -0.56875 & 0.45883 \\
\hline
\end{tabular}

Table 4: Parameters $(\alpha, \sigma)$ at Cung Son gauge

\begin{tabular}{|c|c|c|c|}
\hline $\mathrm{N}$ & Parameters & $\begin{array}{c}\text { Most Probable } \\
\text { value }(\alpha)\end{array}$ & $\begin{array}{c}\text { Standard } \\
\text { deviation } \\
(\sigma)\end{array}$ \\
\hline 1 & Mean (loge flow) & 8.6703 & 0.11562 \\
\hline 2 & Loge [Std dev (loge flow)] & -0.7487 & 0.20568 \\
\hline 3 & Skew (loge flow) & -0.70998 & 0.61295 \\
\hline
\end{tabular}

\section{APPLICATION OF THE METHOD IN CALIBRATION PROCESS}

\section{Catchment modelling system}

As the catchment is large (catchment area of $13,900 \mathrm{~km}^{2}$ ), subdivision of catchment was needed. The subdivision into 155 subcatchments is shown in Figure 4. During calibration, each subcatchment requires values for 10 parameters. The total system, therefore, requires estimation of 1550 parameters.

The catchment modelling system was run with an hourly time step for the period from 1980 to 2011 to generate flow sequences for subsequent flood frequency analysis. The objective function for assessing the calibration of the system was based on the capacity of the generated flow sequence to replicate the flood flow statistics at two gauges, An Khe and Cung Son; in other words, the objective function used during calibration was reproduction of the LP-III statistics obtained for the AMS extracted from the recorded data at the two gauging stations. These flood flow statistics were the mean, standard deviation and skewness of the assumed LP-III distribution and the standard variation of these LP-III parameters (see Table 4 and 5). This study used a GLUE approach in selection of accepted parameter sets; acceptance was based on a threshold of one standard deviation for each of the LP-III parameters at the two gauges (see Tables $5 \& 6$ ).

\section{Preliminary Subcatchment Parameter Estimation}

Initial model parameter values were estimated using various sources such as land use and land cover maps, the DEM, and soil maps. In this case, applying SCS method (US Army Corps of Engineers 2010), the initial estimate of the curve number map was developed using a combination of soil and land 
cover maps. In a similar manner, initial estimates of the roughness coefficients for the sub-catchments were obtained using the slope and land cover maps. Maps of these parameter values were developed in a gridded format at a horizontal resolution of $2000 \mathrm{~m}$ consistent with the rainfall grid data. Once the value of parameters had been estimated for individual grids, the average value for each sub-catchment was determined. An example of the initial values is shown in Figure 4 where the initial $\mathrm{CN}$ values at each subcatchment are illustrated.
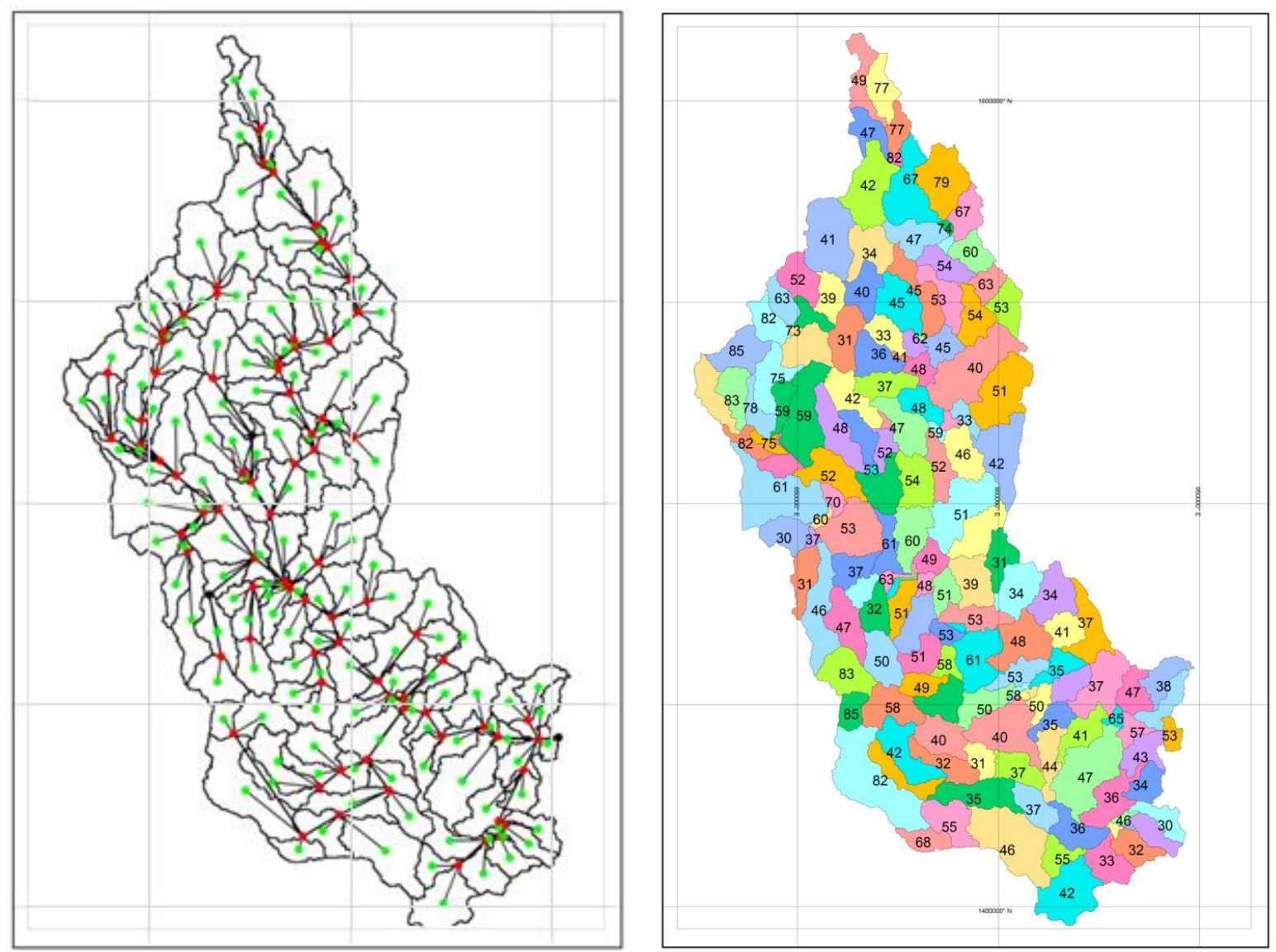

Figure 4: Catchment delineation, stream network and Subcatchment Curve Number

\section{Parameter consideration}

While computational requirements have become a less limiting constraint, a large number of parameter sets is required to estimate values of 1550 parameters.

Sensitivity analyses of HEC-HMS model parameters have been reported by, for example, Al-Hamdan (2009), Eslamian (2014), Kousari et al. (2010), and US Army Corps of Engineers (2000). From analysis of these studies, it has been found that there are 5 parameter categories that are sensitive and need to be considered during the calibration process. These categories are the subcatchment Curve Number, subcatchment representative length, subcatchment representative slope, subcatchment 
overland-flow roughness coefficient and channel reach Manning's roughness coefficient. As a result, only 775 parameters in the catchment modelling system need to be calibrated. Application of the mean and the variation coefficients as proposed herein for the 5 sensitive parameter categories reduces the number of parameter significantly from 775 to only 10 coefficients.

Within the 5 sensitive parameter categories, the Curve Number is the dominant parameter for predicting the runoff depth from the given rainfall while the the rainfall and runoff processes across the subcatchment surfaces and the channel reaches in the catchment are described by the remaining four parameters. Among these parameters, the the catchment lag is characterized by the subcatchment slope, the representative subcatchment length and the subcatchment roughness.

Application of a variation coefficient $\left(\mathrm{K}_{2}\right)$ for all the parameters influencing runoff processes will result in noise or accumulation of adjusted values. Therefore, selection of one variation coefficient for each process in rainfall-runoff model was preferred. As a result, the variation coefficient was applied to three parameters, namely Curve Number, Catchment Roughness and Channel Roughness. The number of parameters, therefore, was reduced to 8 coefficients; these coefficients were $K_{1}$ for curve number $\left(K_{1}-\right.$ $\mathrm{CN}) ; \mathrm{K}_{2}$ for curve number $\left(\mathrm{K}_{2}-\mathrm{CN}\right) ; \mathrm{K}_{1}$ for subcatchment slope $\left(\mathrm{K}_{1}\right.$ - Slope); $\mathrm{K}_{1}$ for subcatchment length ( $K_{1}$ - length); $K_{1}$ for subcatchment roughness ( $K_{1}$ - Catchment roughness); $K_{2}$ for subcatchment roughness ( $\mathrm{K}_{2}-$ Catchment roughness); $\mathrm{K}_{1}$ for channel Manning ( $\mathrm{K}_{1}-$ Channel Manning) and; $\mathrm{K}_{2}$ for channel Manning $\left(\mathrm{K}_{2}-\right.$ Channel Manning).

\section{Calibration process}

The calibration process was developed using a GLUE approach (Beven and Freer, 2001; Blasone et al., 2008; Jin et al., 2010) with constraints imposed that the parameter values must lie within acceptable ranges. The approach included the generation of 600 parameter sets (samples) at every iteration with each parameter set consisting of 775 parameters. The parameter sets which produced AMS statistics within the threshold of the LP-III parameters for the historical data (Table 5 and 6) were selected as acceptable parameter sets.

Table 5: Threshold of parameters $(\alpha, \sigma)$ at An Khe

\begin{tabular}{|c|l|c|c|c|}
\hline \multirow{2}{*}{$\mathrm{N}$} & \multicolumn{1}{|c|}{ Parameters } & $\begin{array}{c}\text { Most Probable value } \\
(\alpha)\end{array}$ & \multicolumn{2}{|c|}{ Threshold } \\
\cline { 4 - 5 } & & 7.0422 & Min & Max \\
\hline 2 & Mean (loge flow) & $\begin{array}{l}\text { Loge [Std dev (loge } \\
\text { flow)] }\end{array}$ & -0.74320 & 7.13238 \\
\hline 3 & Skew (loge flow) & -0.56875 & -1.0275 & -0.1099 \\
\hline
\end{tabular}


Table 6: Threshold of parameters $(\alpha, \sigma)$ at Cung Son gauge

\begin{tabular}{|c|c|c|c|c|}
\hline \multirow{2}{*}{$\mathrm{N}$} & Parameters & Most Probable & \multicolumn{2}{|c|}{ Threshold } \\
\cline { 4 - 5 } & value $(\alpha)$ & Min & Max \\
\hline 1 & Mean (loge flow) & 8.6703 & 8.55468 & 8.78592 \\
\hline 2 & $\begin{array}{c}\text { Loge [Std dev (loge } \\
\text { flow)] }\end{array}$ & -0.7487 & -0.95438 & -0.5430 \\
\hline 3 & Skew (loge flow) & -0.70998 & -1.32293 & -0.0970 \\
\hline
\end{tabular}

The generation of model parameter sets was through adjustment of the $K_{1}$ and $K_{2}$ coefficients applied for each parameter category. Using $\mathrm{CN}$ as an example, the process was:

Step 1: Estimation of initial parameter values;

Step 2: Calculate mean of initial $\mathrm{CN}$ values of 155 subcatchments $\left(\overline{C N_{0}}\right)$;

Step 3: Randomly generate values of coefficients $\mathrm{K}_{1} \_\mathrm{CN}$ and $\mathrm{K}_{2} \_\mathrm{CN}$ within acceptable range following uniform distribution; and

Step 4: Calculate the new values of $\mathrm{CN}$ at subcatchment $\mathrm{i}$ for sample $\mathrm{j}\left(C N_{i, j}\right)$ by application of the following equation:

$$
C N_{i, j}=K_{1-} \mathrm{CN}\left[\overline{C N_{0}}+\left(C N_{i, 0}-\overline{C N_{0}}\right) K_{2-} \mathrm{CN}\right]
$$

where $C N_{i, 0}$ is the initial value of $\mathrm{CN}$ at subcatchment $\mathrm{i}$.

Using this approach, the change in $\mathrm{CN}$ values for 155 subcatchments will be conducted by adjustment of $\mathrm{K}_{1} \_\mathrm{CN}$ and $\mathrm{K}_{2} \mathrm{CN}$. Hence, instead of amending $155 \mathrm{CN}$ values to generate a new parameter set, adjustment of only 2 coefficients $\mathrm{K}_{1} \_\mathrm{CN}$ and $\mathrm{K}_{2} \mathrm{CN}$ is needed.

The same steps were applied for the other parameter categories. The adjustment of 775 parameter values, therefore, was conducted via 8 coefficients. For this case study, 600 parameter sets were generated by by random combination of the 8 coefficients.

To highlight the advantage of application of variation coefficient in non-linear shifting parameter values across the catchment, the approach was tested at 2 gauges An Khe located at upstream catchment area and Cung Son at catchment outlet. Two cases studies were conducted for comparison including:

1. Application of only mean coefficients (variation coefficient equal 1 for all 600 parameter sets)

2. Application of both mean and variation coefficients 


\section{RESULTS}

Case 1: Application of only mean coefficient

Within 600 parameter sets generated by application of only mean coefficient, 100 parameter sets were found to produce LP-III parameters of AMS fitted within confident limits of the frequency curve at the upstream gauge An Khe. At the downstream gauge (Cung Son), 43 acceptable parameter sets were found. However, only one parameter set (

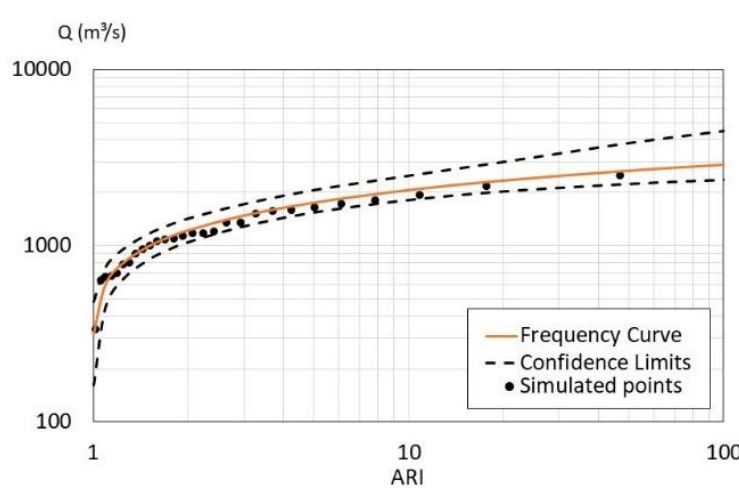

(a)

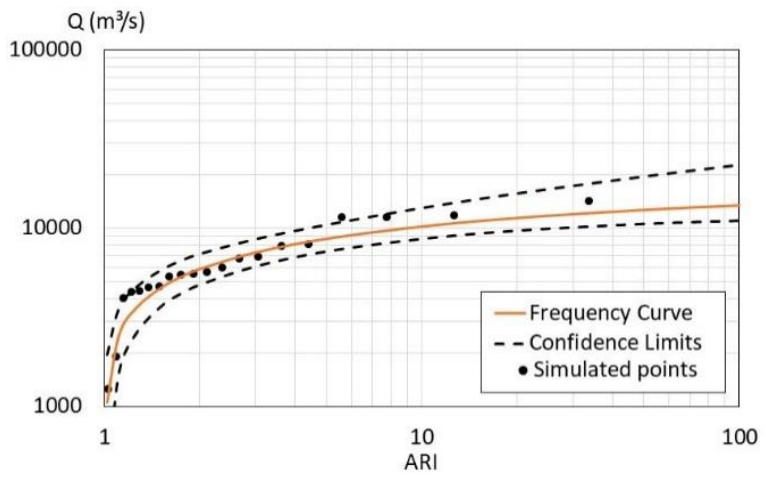

(b)

Figure 5, Table 7) resulted in acceptable AMS statistics at both the upstream and downstream gauges

Table 7: Calibrated coefficients - case 1

\begin{tabular}{|l|l|}
\hline \multicolumn{1}{|c|}{ Coefficient } & Value \\
\hline $\mathrm{K}_{1}-\mathrm{CN}$ & 0.796 \\
\hline $\mathrm{K}_{1}-$ Slope & 0.273 \\
\hline $\mathrm{K}_{1}-$ Catchment length & 1.097 \\
\hline $\mathrm{K}_{1}-$ Catchment roughness & 0.913 \\
\hline $\mathrm{K}_{1}-$ Channel manning & 1.725 \\
\hline
\end{tabular}

The 20 best parameter sets at each gauge station were selected for testing the suitability. Whilst the best 20 parameter sets at An Khe gauges - Case 1a (Figure 6a) resulted in a good fit at the An Khe gauge, they overestimated the flow quantiles at Cung Son gauge (Figure 6b). Conversely, the best 20 
parameter sets at Cung Son gauge - Case $1 \mathrm{~b}$ - produced a good fit at the Cung Son gauge (Figure $7 \mathrm{~b}$ ) but underestimated the flow quantiles at An Khe gauge (Figure 7a).

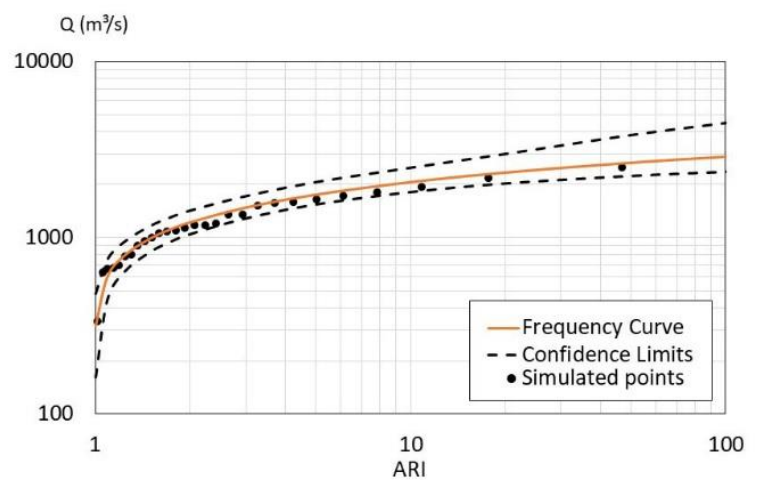

(a)

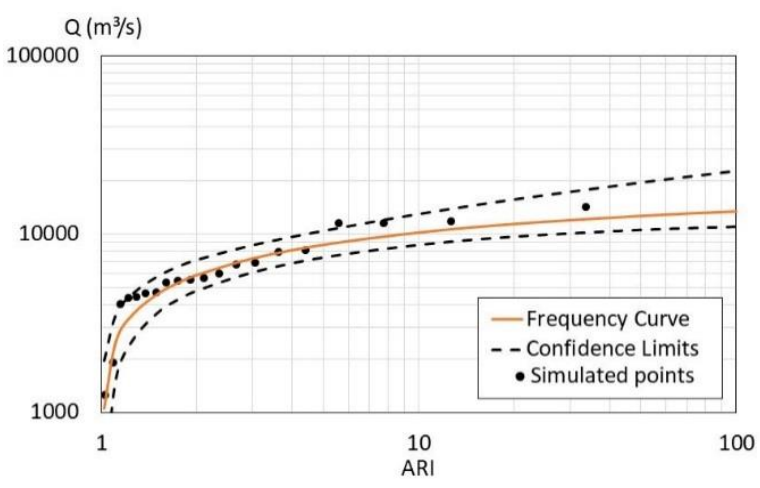

(b)

Figure 5: Frequency analysis of simulated AMS against observed frequency curve at An Khe (a) and Cung Son (b) gauge-Case 1.

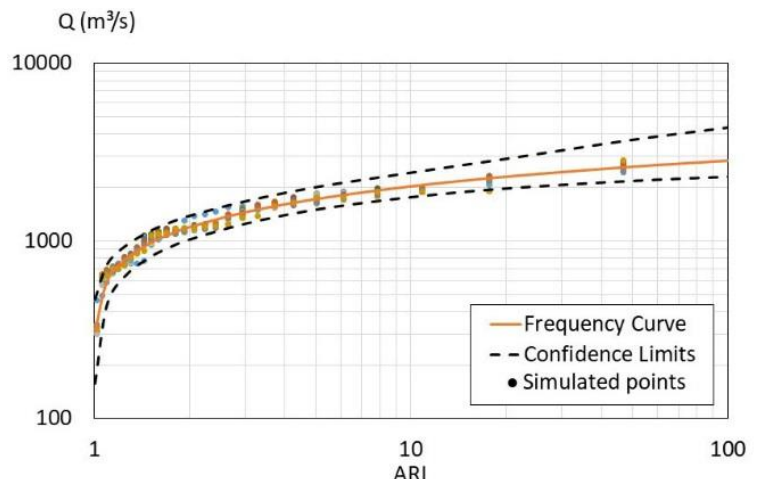

(a)

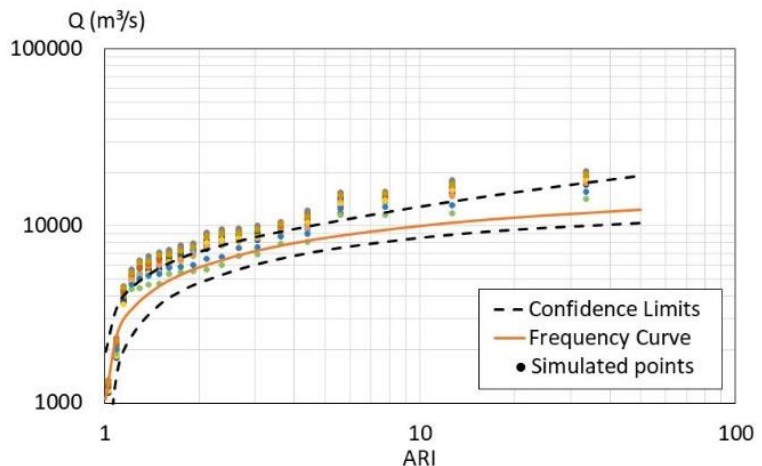

(b)

Figure 6: Frequency analysis of AMS at An Khe (a) and Cung Son (b) gauge, case 1a.

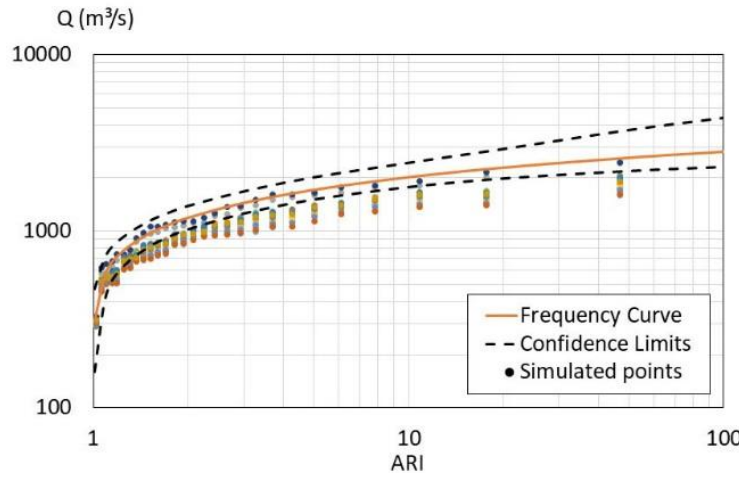

(a)

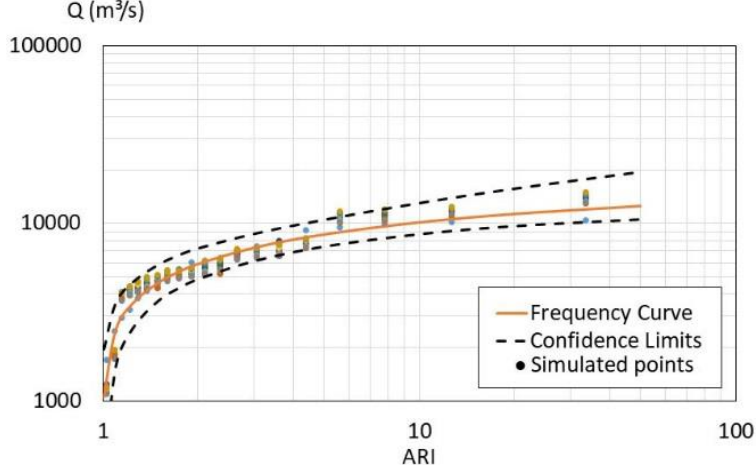

(b)

Figure 7: Frequency analysis of AMS at An Khe Son (a) and Cung Son (b) gauge case 1 b. 
Case 2: Application of Both Coefficients

The same methodology to Case 1 was used to select suitable parameter sets; 600 parameter sets were generated. Compared with Case 1, 24 parameter sets resulted in acceptable fits at the upstream An Khe gauge and 95 parameter sets resulted in acceptable fits at the downstream Cung Son gauge. However, in this case, 23 parameter sets resulted in acceptable fits at both gauges. Acceptable coefficients of the system are shown in Table 8. Consideration of Figure 8 reveals a good fit at the An Khe station and a tendency to overestimate flow at the Cung Son gauge. Overall, it was considered that there is a good fit between the simulated AMSs and the recorded AMS at the two gauges.

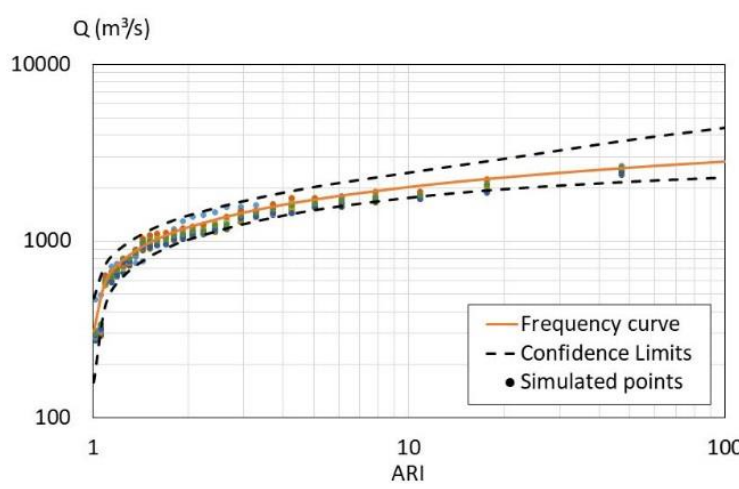

(a)

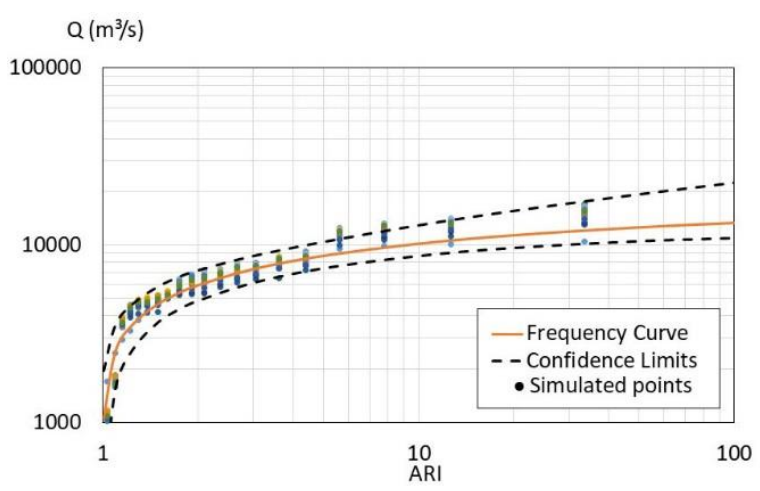

(b)

Figure 8: Frequency analysis of simulated AMS against observed frequency curve at An Khe (a) and Cung Son (b) gauge-Case 2.

Table 8: Calibrated coefficients - case 2

\begin{tabular}{|c|c|c|c|c|c|c|c|c|}
\hline $\begin{array}{c}\text { Parameter } \\
\text { Set - N }\end{array}$ & $\begin{array}{c}\mathrm{K}_{2}- \\
\mathrm{CN}\end{array}$ & $\begin{array}{c}\mathrm{K}_{2}- \\
\mathrm{CN}\end{array}$ & $\begin{array}{c}K_{1}- \\
\text { Slope }\end{array}$ & $\begin{array}{c}K_{1}- \\
\text { Catchment } \\
\text { Length }\end{array}$ & $\begin{array}{c}K_{1}- \\
\text { Catchment } \\
\text { roughness }\end{array}$ & $\begin{array}{c}K_{2}- \\
\text { Catchment } \\
\text { roughness }\end{array}$ & $\begin{array}{c}K_{1}- \\
\text { Channel } \\
\text { Manning }\end{array}$ & $\begin{array}{c}K_{2}- \\
\text { Channel } \\
\text { Manning }\end{array}$ \\
\hline 1010 & 0.70 & 1.95 & 0.84 & 1.93 & 1.91 & 1.12 & 1.59 & 1.46 \\
\hline 1071 & 0.79 & 0.19 & 0.18 & 2.90 & 0.95 & 4.24 & 0.87 & 1.43 \\
\hline 1081 & 0.76 & 0.15 & 0.95 & 1.39 & 2.37 & 0.77 & 1.94 & 4.40 \\
\hline 1116 & 0.81 & 1.80 & 0.61 & 1.28 & 2.66 & 4.40 & 2.50 & 0.26 \\
\hline 1118 & 0.87 & 0.87 & 0.52 & 2.56 & 2.03 & 3.03 & 1.20 & 1.03 \\
\hline 1217 & 0.87 & 1.29 & 0.70 & 1.68 & 1.07 & 2.90 & 2.08 & 4.75 \\
\hline 1246 & 0.70 & 1.24 & 0.83 & 2.63 & 1.49 & 0.22 & 2.06 & 0.55 \\
\hline 1248 & 0.82 & 0.39 & 0.77 & 1.52 & 0.97 & 3.11 & 1.99 & 3.72 \\
\hline 1261 & 0.56 & 0.25 & 0.72 & 1.16 & 2.70 & 1.72 & 2.47 & 4.32 \\
\hline 1266 & 0.67 & 0.63 & 0.95 & 2.58 & 2.23 & 3.19 & 1.76 & 4.21 \\
\hline 1270 & 0.55 & 0.59 & 0.42 & 1.72 & 1.08 & 2.67 & 1.22 & 4.08 \\
\hline 1293 & 0.69 & 1.73 & 0.88 & 2.04 & 1.62 & 0.37 & 1.93 & 3.70 \\
\hline 1303 & 0.56 & 1.86 & 0.79 & 1.85 & 1.76 & 2.67 & 2.99 & 4.86 \\
\hline 1353 & 0.62 & 1.01 & 0.55 & 2.39 & 1.38 & 4.54 & 1.16 & 3.03 \\
\hline 1392 & 0.56 & 1.13 & 0.82 & 2.28 & 1.22 & 0.79 & 1.48 & 1.02 \\
\hline 1398 & 0.66 & 1.71 & 0.85 & 2.23 & 1.70 & 2.79 & 2.55 & 4.19 \\
\hline 1424 & 0.79 & 1.19 & 0.53 & 2.88 & 0.90 & 3.63 & 2.79 & 4.83 \\
\hline 1439 & 0.65 & 1.40 & 0.79 & 1.93 & 2.43 & 2.90 & 1.05 & 3.89 \\
\hline
\end{tabular}




\begin{tabular}{|l|l|l|l|l|l|l|l|l|}
\hline 1462 & 0.73 & 1.16 & 0.32 & 1.92 & 1.72 & 3.46 & 1.07 & 3.62 \\
\hline 1463 & 0.73 & 1.92 & 0.30 & 1.12 & 2.45 & 2.28 & 1.60 & 2.02 \\
\hline 1467 & 0.57 & 0.83 & 0.24 & 2.12 & 2.32 & 3.78 & 1.68 & 4.95 \\
\hline 1481 & 0.72 & 0.88 & 0.52 & 2.08 & 1.71 & 0.43 & 2.01 & 4.34 \\
\hline 1508 & 0.60 & 1.09 & 0.19 & 1.17 & 0.82 & 4.95 & 2.52 & 2.04 \\
\hline
\end{tabular}

Table 9 shows the results of a correlation test between coefficients of the system. As can be seen from this table, all values of the test were less than 0.80 . This indicates that the use of a variation coefficient enabled non-linear shifting of the parameter values during the calibration process.

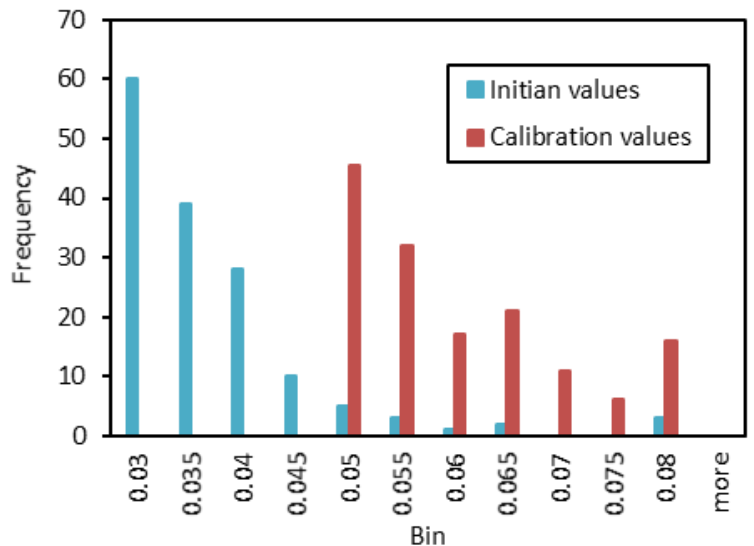

(Case 1)

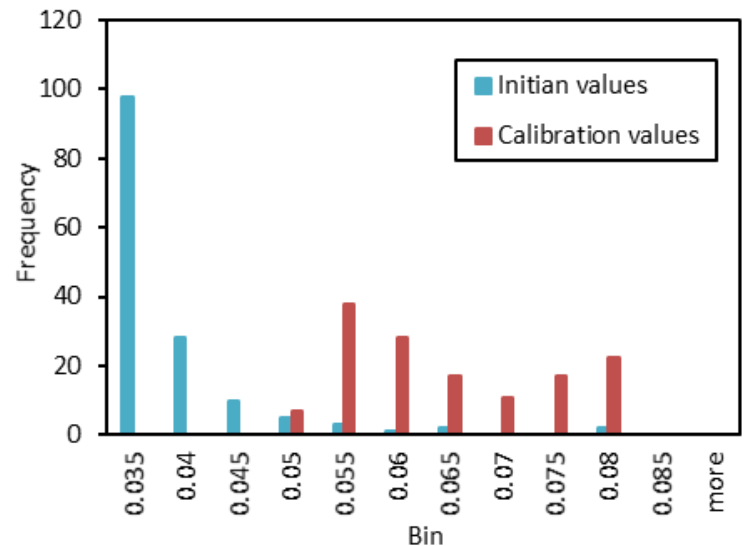

(Case 2)

Figure 9: Spatial distribution of Channel Manning values across the catchment (initial values vs. calibration values)

Table 9: Correlation between coefficients

\begin{tabular}{|c|c|c|c|c|c|c|c|c|}
\hline Coefficient & $\begin{array}{l}\mathrm{K}_{2}- \\
\mathrm{CN}\end{array}$ & $\begin{array}{l}\mathrm{K}_{2}- \\
\mathrm{CN}\end{array}$ & $\begin{array}{l}K_{1-} \\
\text { Slope }\end{array}$ & $\begin{array}{c}K_{1-}- \\
\text { Catchment } \\
\text { Length }\end{array}$ & $\begin{array}{c}K_{1-} \\
\text { Catchment } \\
\text { roughness }\end{array}$ & $\begin{array}{c}\mathrm{K}_{2}- \\
\text { Catchment } \\
\text { roughness }\end{array}$ & $\begin{array}{c}K_{1-} \\
\text { Channel } \\
\text { Manning }\end{array}$ & $\begin{array}{c}K_{2}- \\
\text { Channel } \\
\text { Manning }\end{array}$ \\
\hline$K_{1}-C N$ & 1 & & & & & & & \\
\hline $\mathrm{K}_{2}-\mathrm{CN}$ & -0.030 & 1 & & & & & & \\
\hline$K_{1}-$ Slope & -0.007 & 0.134 & 1 & & & & & \\
\hline $\begin{array}{l}K_{1}- \\
\text { Catchment } \\
\text { Length }\end{array}$ & 0.122 & -0.10 & 0.038 & 1 & & & & \\
\hline $\begin{array}{l}K_{1}- \\
\text { Catchment } \\
\text { roughness }\end{array}$ & -0.08 & 0.135 & 0.232 & -0.339 & 1 & & & \\
\hline $\begin{array}{l}K_{2}- \\
\text { Catchment } \\
\text { roughness }\end{array}$ & 0.089 & -0.08 & -0.575 & 0.011 & -0.176 & 1 & & \\
\hline $\begin{array}{l}K_{1}- \\
\text { Channel } \\
\text { Manning }\end{array}$ & -0.058 & 0.268 & 0.279 & -0.272 & 0.006 & -0.051 & 1 & \\
\hline
\end{tabular}




\begin{tabular}{|l|r|r|r|r|r|r|r|r|}
\hline $\begin{array}{l}K_{2}- \\
\text { Channel }\end{array}$ & & & & & & & & \\
Manning & -0.203 & -0.21 & 0.133 & -0.071 & 0.009 & 0.004 & 0.258 & 1 \\
\hline
\end{tabular}

The spatial distribution of parameter values across the catchment is plotted in histogram. An example of this is the distribution of Channel Manning values for Case 1 and Case 2. Figure 9 - case 1 shows the distribution of the initial parameter values and the calibration values of Channel Manning parameter in Case 1. As can be seen from Figure 9 - case 1, the values of Channel Manning increased after calibration from 0.034 to 0.058 . For Case 2 (see in Figure 9 - case 2) the proposed approach resulted in shifting of the parameter values and a change in the value frequency. This indicates that the calibration approach using a mean and variation coefficient enables not only adjustment of the parameter values across the catchment but also allows a change in the density distribution of the parameter values.

\section{CONCLUSION AND DISCUSSION}

Using the mean and variation coefficients, the number of model parameters reduced significantly from 755 to 8 coefficients. Adjustment of the parameter values using these coefficients enables changes in the model parameter values over the catchment. This improves the feasibility of the calibration process and the identification of suitable parameter values.

Comparing the proposed approach with the case of a linear shift in the parameter values across the catchment, the application of mean and variation coefficients resulted in a significant improvement in the calibration process resulting in an increase in number of accepted parameter sets. This implies that the method could enhance model parameterisation, especially in cases of large catchments dealing with a large number of parameters and multiple gauging stations.

While the acceptable ranges of model parameters have been reported in many studies (for example, AlHamdan 2009; American Society of Civil Engineers 1949), the acceptable ranges of the coefficients are specified for each case study and depend on the initial values of the model parameters. Therefore, there is a need to carefully analyse the initial condition of modelling system to identify suitable ranges of the coefficients.

A limitation of this study is that no validation process was possible as all available data was used during the calibration process. The method used a continuous simulation approach to generate the flow sequence for flood frequency analysis. This requires long time observations of flow and rainfall for conducting the AMS estimation. For this case study, Ba River, a 32 year simulation period from 1980 to 2011 was used. This limits the option for splitting the observation period into calibration and 
validation segments. In addition, the splitting observation period will result in shorter AMS records and wider confidence limits.

\section{ACKNOWLEDGMENTS}

Support for the first author was provided by a VIED - UTS scholarship. The support of both the Australian and Vietnamese partners in this scholarship scheme is gratefully acknowledged.

\section{REREFENCES}

AL-HAMDAN, O. 2009, Sensitivity Analysis of HEC-HMS Hydrologic Model to the Number of Sub-Basins: Case Study, World Environmental and Water Resources Congress 2009, pp. 1-9.

AMERICAN SOCIETY OF CIVIL ENGINEERS 1949, Hydrology Handbook, ASCE New York.

AMIR, M. S. I. I., KHAN, M. M. K., RASUL, M. G., SHARMA, R. H. \& AKRAM, F. 2013. Automatic Multi-Objective Calibration of a Rainfall Runoff Model for the Fitzroy Basin, Queensland, Australia. International Journal of Environmental Science and Development, 3, 311 .

BALL, J.E. \& CU, T.P. 2014, Daily Rainfall Disaggregation for a Monsoon Catchment in Vietnam, Hydrology \& Water Resources Symposium, Perth, Australia.

BALlESTEROS, J. A., BODOQUE, J. M., DÍEZ-HERRERO, A., SANCHEZ-SILVA, M. \& STOFFEL, M. 2011. Calibration of floodplain roughness and estimation of flood discharge based on tree-ring evidence and hydraulic modelling. Journal of Hydrology, 403, 103-115.

BEVEN, K. \& FREER, J. 2001. Equifinality, data assimilation, and uncertainty estimation in mechanistic modelling of complex environmental systems using the GLUE methodology. Journal of Hydrology, 249, 11-29.

BLASONE, R.-S., MADSEN, H. \& ROSBJERG, D. 2008, Uncertainty assessment of integrated distributed hydrological models using GLUE with Markov chain Monte Carlo sampling, Journal of Hydrology, vol. 353, no. 1-2, pp. 18-32.

CAMERON, D., BEVEN, K., TAWN, J. \& NADEN, P. 1999. Flood frequency estimation by continuous simulation (with likelihood based uncertainty estimation). Hydrol. Earth Syst. Sci., 4, 23-34. 
CHENG, Q.-B., CHEN, X., XU, C.-Y., REINHARDT-IMJELA, C. \& SCHULTE, A. 2014. Improvement and comparison of likelihood functions for model calibration and parameter uncertainty analysis within a Markov chain Monte Carlo scheme. Journal of Hydrology, 519, Part B, 2202-2214.

CU, P. \& BALL, J. 2016. The influence of the calibration metric on design flood estimation using continuous simulation. International Journal of River Basin Management, DOI: 10.1080/15715124.2016.1239623.

DEL GIUDICE, D., HONTI, M., SCHEIDEGGER, A., ALBERT, C., REICHERT, P. \& RIECKERMANN, J. 2013. Improving uncertainty estimation in urban hydrological modeling by statistically describing bias. Hydrology \& Earth System Sciences, 17, 4209-4225.

DUNG, N. V., MERZ, B., BÁRDOSSY, A. \& APEL, H. 2015. Handling uncertainty in bivariate quantile estimation - An application to flood hazard analysis in the Mekong Delta. Journal of Hydrology, 527, 704-717.

DUONG, V. N. \& GOURBESVILLE, P. 2016. Model Uncertainty in Flood Modelling. Case Study at Vu Gia Thu Bon Catchment - Vietnam. Procedia Engineering, 154, 450-458.

EBRAHIM, G., JONOSKI, A., AL-MAKTOUMI, A., AHMED, M. \& MYNETT, A. 2016, Simulation-Optimization Approach for Evaluating the Feasibility of Managed Aquifer Recharge in the Samail Lower Catchment, Oman, Journal of Water Resources Planning and Management, vol. 142, no. 2, p. 05015007.

ESLAMIAN, S., 2014, (ed.) Handbook of Engineering Hydrology, Vol. 1: Fundamentals and Applications, Francis and Taylor, CRC Group, USA

FANG, T. \& BALL, J.E. 2007, Evaluation of spatially variable control parameters in a complex catchment modelling system: a genetic algorithm application, Journal of Hydroinformatics, vol. 9, no. 3, pp. 163-73.

FAN, Y. R., HUANG, G. H., BAETZ, B. W., LI, Y. P., HUANG, K., LI, Z., CHEN, X. \& XIONG, L. H. 2016. Parameter uncertainty and temporal dynamics of sensitivity for hydrologic models: A hybrid sequential data assimilation and probabilistic collocation method. Environmental Modelling \& Software, 86, 30-49.

FRANZ, K. J. \& HOGUE, T. S. 2011. Evaluating uncertainty estimates in hydrologic models: borrowing measures from the forecast verification community. Hydrology \& Earth System Sciences Discussions, 8, 3085-3131 
HALBERT, K., NGUYEN, C. C., PAYRASTRE, O. \& GAUME, E. 2016. Reducing uncertainty in flood frequency analyses: A comparison of local and regional approaches involving information on extreme historical floods. Journal of Hydrology, 541, Part A, 90-98.

HMDC 2012, Rainfall and flow data at Ba river catchment in Vietnam, Hydrometeorological Data Center, The Vietnam Institute of Meteorology, Hydrology and Environment (IMHEN).

HOUSKA, T., MULTSCH, S., KRAFT, P., FREDE, H.-G. \& BREUER, L. 2014, Monte Carlobased calibration and uncertainty analysis of a coupled plant growth and hydrological model, Biogeosciences, vol. 11, pp. 2069-82.

HUTTON, C., KAPELAN, Z., VAMVAKERIDOU-LYROUDIA, L. \& SAVIĆ, D. 2014, Application of Formal and Informal Bayesian Methods for Water Distribution Hydraulic Model Calibration, Journal of Water Resources Planning and Management, vol. 140, no. 11, p. 04014030.

JIN, X., XU, C.-Y., ZHANG, Q. \& SINGH, V.P. 2010, Parameter and modeling uncertainty simulated by GLUE and a formal Bayesian method for a conceptual hydrological model, Journal of Hydrology, vol. 383, no. 3-4, pp. 147-55.

KOUSARI, M.R., MALEKINEZHAD, H., AHANI, H. \& ASADI ZARCH, M.A. 2010, Sensitivity analysis and impact quantification of the main factors affecting peak discharge in the SCS curve number method: An analysis of Iranian watersheds, Quaternary International, vol. 226, no. 1-2, pp. 66-74.

KUCZERA, G. AND FRANKS, S., 2016. At-site flood frequency analysis. In: J. Ball, M. Babister, R. Nathan, W. Weeks, E. Weinmann, M. Retallick and I.Testoni, eds. Australian rainfall and runoff: a guide to flood estimation. Commonwealth of Australia, Chap. 2, Book 3. Available from: http://arr.ga.gov.au/.

KUCZERA, G. \& PARENT, E. 1998. Monte Carlo assessment of parameter uncertainty in conceptual catchment models: the Metropolis algorithm. Journal of Hydrology, 211, 69-85.

KUNDU, D., VAN OGTROP, F. F. \& VERVOORT, R. W. 2016. Identifying model consistency through stepwise calibration to capture streamflow variability. Environmental Modelling \& Software, 84, 1-17. 
LI, Y., RYU, D., WESTERN, A. W., WANG, Q. J., ROBERTSON, D. E. \& CROW, W. T. 2014. An integrated error parameter estimation and lag-aware data assimilation scheme for real-time flood forecasting. Journal of Hydrology, 519, Part D, 2722-2736.

LIU, Y. \& SUN, F. 2010. Sensitivity analysis and automatic calibration of a rainfall-runoff model using multi-objectives. Ecological Informatics, 5, 304-310.

MARTIN, C. \& AYESA, E. 2010, An Integrated Monte Carlo Methodology for the calibration of water quality models, Ecological Modelling, vol. 221, no. 22, pp. 2656-67.

MCMILLAN, H. \& CLARK, M. 2009, Rainfall-runoff model calibration using informal likelihood measures within a Markov chain Monte Carlo sampling scheme, Water Resources Research, vol. 45, no. 4, pp. n/a-n/a.

MANTOVAN, P. \& TODINI, E. 2006. Hydrological forecasting uncertainty assessment: Incoherence of the GLUE methodology. Journal of Hydrology, 330, 368-381.

MATSUMOTO, M. \& NISHIMURA, T. 1998. Mersenne Twister: A 623-dimensionally equidistributed uniform pseudo-random number generator. ACM Transactions on Modeling and Computer Simulation, 8, 3-30.

MCCLOSKEY, G. L., ELLIS, R. J., WATERS, D. K. \& STEWART, J. 2011. PEST hydrology calibration process for source catchments - applied to the Great Barrier Reef, Queensland. 19th International Congress on Modelling and Simulation. Perth Australia. MICOVIC, Z., SCHAEFER, M. G. \& BARKER, B. L. 2017. Chapter 11 - Sensitivity and Uncertainty Analyses for Stochastic Flood Hazard Simulation A2 - Petropoulos, George P. In: SRIVASTAVA, P. K. (ed.) Sensitivity Analysis in Earth Observation Modelling. Elsevier.

MOCKLER, E. M., CHUN, K. P., SAPRIZA-AZURI, G., BRUEN, M. \& WHEATER, H. S. 2016. Assessing the relative importance of parameter and forcing uncertainty and their interactions in conceptual hydrological model simulations. Advances in Water Resources, 97, 299-313.

MONNIER, J., COUDERC, F., DARTUS, D., LARNIER, K., MADEC, R. \& VILA, J. P. 2016. Inverse algorithms for 2D shallow water equations in presence of wet dry fronts: Application to flood plain dynamics. Advances in Water Resources, 97, 11-24.

MIKE by DHI 2011, MIKE 21 \& MIKE 3 Flow Model FM, Denmak.

MULETA, M., MCMILlAN, J., AMENU, G. \& BURIAN, S. 2013, Bayesian Approach for Uncertainty Analysis of an Urban Storm Water Model and Its Application to a Heavily 
Urbanized Watershed, Journal of Hydrologic Engineering, vol. 18, no. 10, pp. 136071.

PARKES, B. \& DEMERITT, D. 2016. Defining the hundred year flood: A Bayesian approach for using historic data to reduce uncertainty in flood frequency estimates. Journal of Hydrology, 540, 1189-1208.

PEREIRA, D. D. R., MARTINEZ, M. A., PRUSKI, F. F. \& DA SILVA, D. D. 2016. Hydrological simulation in a basin of typical tropical climate and soil using the SWAT model part I: Calibration and validation tests. Journal of Hydrology: Regional Studies, 7, 14-37.

PODGER, G. 2004, Rainfall Runoff Library User Manual, Melbourne: CRC for Catchment Hydrology

RASHID, A. A., LIANG, Q., DAWSON, R. J. \& SMITH, L. S. 2016. Calibrating a HighPerformance Hydrodynamic Model for Broad-Scale Flood Simulation: Application to Thames Estuary, London, UK. Procedia Engineering, 154, 967-974.

SCHILLING, O. S., DOHERTY, J., KINZELBACH, W., WANG, H., YANG, P. N. \& BRUNNER, P. 2014. Using tree ring data as a proxy for transpiration to reduce predictive uncertainty of a model simulating groundwater-surface water-vegetation interactions. Journal of Hydrology, 519, Part B, 2258-2271.

SMITH, T., MARSHALL, L. \& SHARMA, A. 2015, Modeling residual hydrologic errors with Bayesian inference, Journal of Hydrology, vol. 528, pp. 29-37.

SINGH, V. P. AND D. K. FREVERT (2006). Watershed Models. Taylor and Francis, Boca Raton, FL, UAS.

THYER, M., KUCZERA, G. \& BATES, B.C. 1999, 'Probabilistic optimization for conceptual rainfall-runoff models: A comparison of the shuffled complex evolution and simulated annealing algorithms', Water Resources Research, vol. 35, no. 3, pp. 767-73.

STEPHENS, E. M., BATES, P. D., FREER, J. E. \& MASON, D. C. 2012. The impact of uncertainty in satellite data on the assessment of flood inundation models. Journal of Hydrology, 414-415, 162-173.

TONKIN, M. \& DOHERTY, J. 2009. Calibration-constrained Monte Carlo analysis of highly parameterized models using subspace techniques. Water Resources Research, 45, W00B10, doi:10.1029/2007WR006678, 2009.

US ARMY CORPS OF ENGINEERS 2000, Hydrologic Modeling System HEC - HMS, Technical Reference Manual, Hydrologic Engineering Center, Davis, CA. 
US Army Corps of Engineers 2010, Hydrologic Modeling System HEC - HMS, User's Manual, Hydrologic Engineering Center, Davis, CA.

VKH KTTV\&MT 2010, Đánh giá tác động của biến đổi khi hậu lên tài nguyên nước và các biện pháp thích ứng - Luu vục sông $B a$, Trung tâm nghiên cứu thủy văn và môi trường, Viện khoa học Khí Tượng Thủy văn \& Môi trường Hanoi.

VIVIROLI, D., ZAPPA, M., SCHWANBECK, J., GURTZ, J. \& WEINGARTNER, R. 2009. Continuous simulation for flood estimation in ungauged mesoscale catchments of Switzerland - Part I: Modelling framework and calibration results. Journal of Hydrology, 377, 191-207.

VRUGT, J.A., GUPTA, H.V., BOUTEN, W. \& SOROOSHIAN, S. 2003, A Shuffled Complex Evolution Metropolis algorithm for optimization and uncertainty assessment of hydrologic model parameters, Water Resources Research, vol. 39, no. 8, DOI: 10.1029/2002WR001642.

VRUGT, J.A., TER BRAAK, C.J.F., DIKS, C.G.H. \& SCHOUPS, G. 2013, Hydrologic data assimilation using particle Markov chain Monte Carlo simulation: Theory, concepts and applications, Advances in Water Resources, vol. 51, pp. 457-78.

WANG, J., LIANG, Z., HU, Y. \& WANG, D. 2015. Modified weighted function method with the incorporation of historical floods into systematic sample for parameter estimation of Pearson type three distribution. Journal of Hydrology, 527, 958-966.

YUCEL, I., ONEN, A., YILMAZ, K. K. \& GOCHIS, D. J. 2015. Calibration and evaluation of a flood forecasting system: Utility of numerical weather prediction model, data assimilation and satellite-based rainfall. Journal of Hydrology, 523, 49-66.

ZHANG, Y., SHAO, Q., ZHANG, S., ZHAI, X. \& SHE, D. 2016. Multi-metric calibration of hydrological model to capture overall flow regimes. Journal of Hydrology, 539, 525538.

ZORN, C. R. \& SHAMSELDIN, A. Y. 2015. Peak flood estimation using gene expression programming. Journal of Hydrology, 531, Part 3, 1122-1128. 